\title{
Effect of different accellerators and inoculums used in fermentation on quality of dead chicken silage flour as feed ingredient for catfish
}

\author{
B. Bakrie, Y. Sastro and N. R. Sudolar \\ Jakarta Assessment Institute of Agricultural Technology , \\ Jl. Raya Ragunan No.30, Kelurahan Jati Padang, \\ Kecamatan Pasar Minggu, Jakarta 12540 - Indonesia \\ CorrespondingE-mail: bachtarbakrie@yahoo.com
}

Received October 06, 2016; Accepted January 24, 2017

\begin{abstract}
ABSTRAK
Penelitian ini bertujuan untuk mempelajari pengaruh penggunaan bahan aditif berupa molases dan tepung jagung serta inokulum berupa bakteri Lactobacillus sp. dan Streptomyces sp., terhadap kualitas tepung silase berbahan baku ayam mati. Penelitian dilakukan menggunakan rancangan acak lengkap pola faktorial, terdiri atas 2 faktor dengan 5 ulangan. Faktor pertama adalah jenis bahan aditif dan faktor kedua adalah jenis inokulum yang digunakan pada saat fermentasi. Bahan yang digunakan berupa ayam mati segar dan utuh yang telah digiling dan semua bahan dicampur secara merata, lalu dimasukkan ke dalam kotak plastik berukuran 5 liter, kemudian ditutup rapat dan diberi plaster/lakban untuk menciptakan suasana anaerob. Pengamatan dilakukan setelah difermentasikan selama 3 minggu, meliputi: a) Karakteristik fisik, b) Kandungan mikroba, dan c) Kandungan gizi. Data yang diperoleh diolah dengan analsis ragam menggunakan program komputer SPSS versi 21.0. Diperoleh hasil bahwa berdasarkan kandungan protein maka Lactobacillus sp. (19.0\%) lebih baik daripada Streptomyces sp. jika digunakan bersamaan dengan molases dan tepung jagung. Akan tetapi penggunaan kedua jenis inoculum tersebut akan menghasilkan kandungan lemak yang relatif sama (rataan 37,8\%). Disimpulkan bahwa untuk memperoleh hasil fermentasi yang baik berdasarkan kandungan protein dan lemak, maka sebaiknya ayam mati difermentasikan menggunakan molases dan tepung jagung sebagai akselerator serta Lactobacillus sp. sebagai inokulum.
\end{abstract}

Kata kunci: akselerator, ayam mati, fermentasi, inokulum, tepung silase

\begin{abstract}
This research aimed at investigating the effect using molasses and cornmeal as additives with Lactobacillus sp. and Streptomyces sp. as inoculums during fermentation on the quality of silage flour made from dead chickens. The study was conducted using a completely randomized factorial design, consisting of 2 factors with 5 replications. The materials used were the newly dead chickens which were chopped and mixed thoroughly with all ingredients; then transferred into a 5 liters plastic box for fermentation. Observations were made after 3 weeks fermentation, including: a) physical characteristics, b) microbial contents, and c) nutritional contents. The data were calculated using variance analysis utilizing computer program of SPSS version 21.0. It was found that based on the protein contents the Lactobacillus sp. (19.0\%) was better than the Streptomyces sp. (17.8\%) if combined with molasses and corn meal as the accelerators. However, the fat contents produced were relatively similar for both of the inoculums (mean of 37.8\%). It can be concluded that in order to obtain a best fermented product in terms of the protein and fat content, the dead chicken should be fermented using molasses and cornmeal as the accelerator and Lactobacillus sp. as the inoculum.

Keywords: accelerator, dead chickens, fermentation, inoculum, silage flour
\end{abstract}




\section{INTRODUCTION}

The average number of live broiler chicken brought to Jakarta in the last 5 years is about 430,648 head per day (Ditjen PKH, 2015). However, during the days of religious festivals such as Eid al-Fitr, Eid al-Adha, Christmas and New Year, as the level of consumption of chicken meat increased, then the number of chicken brought from outside the city is up to 1 million head per day. The birds were mainly come from provinces of West Java, Banten, Central Java, Yogyakarta and Lampung, and usually come through the main entrance of Tangerang, Depok, Bogor, Karawang and Bekasi.

Transporting chickens from the farm to the market/collecting point or to the slaughterhouse could cause the death of the chickens. The death of the chicken was primarily due to exhaustion during the journey, due to long traveling, weather, shock and crammed in the transporting basket. Results of several studies reported that the death rate of chickens' transportation ranged between 0.12 to $1.64 \%$ (Nijdam et al., 2006; Haslam et al., 2008; Chauvin et al., 2011). Mileage and long trips can affect chicken mortality rate, which increased from $0.59 \%$ on a trip with a distance of less than $50 \mathrm{~km}$ to $1.64 \%$ if the distance reached $300 \mathrm{~km}$ (Voslarova et al., 2007). Travel for 3.5 hours resulting in the death of chickens as much as $0.24 \%$ and with the ride of over 5 hours led to an increased number of chickens died almost twofold to $0.45 \%$ (Petracci et al., 2005).

Results of study or report on the death rate of chicken due to travel to the slaughterhouse in Jakarta or other areas in Indonesia had never been available. If it is assumed that the average mortality rate of chickens transported to the area of Jakarta is approximately of $1 \%$ per day, then the number of dead chickens may be traded as dead chicken is as much as 4.000 to 10.000 birds per day.

The dead chicken is a chicken that does not cut perfectly, so there are still many blood clots in the flesh. Blood clots are good growth media for microorganisms, especially Salmonella sp. and Escherichia coli (E. coli), which is very dangerous for the health of people who consume it. Nearly $10 \%$ of the 1.4 million cases of food poisoning per year have been reported in several countries due to Salmonellosis (Core, 2005; Kinley et al., 2010).

The usual way of handling a dead chicken is by combustion or incineration, burial, composting (for fertilizer) and processing as raw materials for animal or fish (Shata and Farid, 2013). In addition, a technology that is also quite appropriate for the handling of dead chickens is the fermentation technology. The principle of the implementation of the fermentation is to stop contact between the fermented material with air or oxygen. It is necessary to ensure that during the fermentation process an acidic condition is reached, i.e. through the addition of soluble carbohydrates, such as molasses, cassava, rice bran, cornmeal, etc. (Jamarun et al., 2014). In addition, it is also necessary to add lactic acid bacteria (LAB), such as Lactobacillus sp., Pediococus sp, or Streptococcus sp. The addition of LAB will lead to increased production of lactic acid, which will create an acidic condition characterized by a decrease in $\mathrm{pH}$. Low $\mathrm{pH}$ levels will inhibit the growth of viruses, pathogenic bacteria (especially Clostridium and Enterobacterium), yeasts and fungi that cause decay (Heinritz, 2011; Utomo et al., 2013).

In relation to the dead chickens which were fermented in the form of a whole chicken, consists of meat, bones, heads, feet, viscera and feather, then the possibility that other materials that can help to degrade these materials should also be added. Chicken feathers containing a high level of crude protein, around $80-91 \%$, but it have a very low digestibility because most of the structure of the feathers consists of keratin proteins belonging to the fiber protein (Manivasagan et al., 2013). One type of bacteria that can produce keratinase to degrade keratin is Streptomyces sp. (Jani et al., 2014).

The objective of this study was to investigate the role of carbohydrate as fermentation accelerator during the fermentation process of the whole dead chicken. Furthermore, this investigation was also made to determine the proper inoculum (Streptomyces sp. or Lactobacillus sp.) degrading the keratin contained in chicken feathers.

\section{MATERIALS AND METHODS}

\section{Experimental Design and Treatments}

This study was conducted using a completely randomized factorial design consisting of 2 factors with 5 replicates. The first factor was 2 types of fermentation accelerators, namely: a) $20 \%$ molasses (Accelerator-1), b) a mixture of $20 \%$ molasses and $20 \%$ cornmeal (Accelerator-2). The second factor was three types of bacteria as 
inoculums, namely: a) $10^{6} \mathrm{cfu} / \mathrm{g}$ Lactobacillus sp. (Inoculum-1), b) $10^{6} \mathrm{cfu} / \mathrm{g}$ Streptomyces sp. (Inoculum-2), c) a mixture of $10^{6} \mathrm{cfu} / \mathrm{g}$ Lactobacillus sp. and $10^{6} \mathrm{cfu} / \mathrm{g}$ Streptomyces sp. (Inoculum-3). Thus, there were six treatments: a) Accelerator-1 + Inoculum-1, b) Accelerator-1 + Inoculum-2, c) Accelerator-1 + Inoculum-3, d) Accelerator-2 + Inoculum-1, e) Accelerator-2 + Inoculum-2, f) Accelerator-2 + Inoculum-3.

\section{Inoculums Preparation}

The propagation of isolates Lactobacillus sp. and Streptomyces sp. was carried out in two stages. The first stage was re-growing them in an agar medium slant, while the second stage was propagation in a liquid medium. The media used for this purpose were the trypticase soy agar (TSA) for the Lactobacillus sp. and the potatoes dextrose agar (PDA) for the Streptomyces sp. The TSA media consisted of $30 \mathrm{~g}$ of trypticase soy broth (TSB) and $15 \mathrm{~g}$ agar, while the PDA media comprised of $100 \mathrm{ml}$ of potato extract, $20 \mathrm{~g}$ of sucrose and 20 grams of agar. Each media was then added with distilled water up to $1000 \mathrm{ml}$ volume, heated to boiling and sterilized in an autoclave at a pressure of 1 atmosphere for 15 minutes. Each inoculum was grown on an agar medium slant by scraping a wire loop containing bacterial cells on the surface of agar medium and it was finally incubated in the incubator for 5 days (Steubing, 1993; Bujalance et al., 2006).

The propagation of inoculum Lactobacillus sp. and Streptomyces sp. in the liquid medium was carried out in a $500 \mathrm{ml}$ erlenmeyer flask which contained $200 \mathrm{ml}$ of TSB and Potatoes Dextrose Liquid (PDL). This media had been previously sterilized in an autoclave at a pressure of 1 atmosphere for 15 minutes and allowed to stand for 24 hours. One loop of each isolate which have had been re-grown in the agar medium slant was inoculated in the liquid medium and subsequently incubated on a shaker at the speed of 100 rotary per minute for 5 days (Steubing 1993). Number of cells that are formed was then counted at the end of incubation period, using a haemocytometer, and it was finally diluted to reach the density of $10^{6}$ cells per $\mathrm{ml}$, prior to the fermentation time.

\section{Fermentation Processes}

Number of dead chickens used in this study was 150 pieces which were collected in the morning, around 4:00 to $6: 00 \mathrm{pm}$, from several collecting points and slaughterhouse located in
East Jakarta. The dead chicken collected was the freshly dead chicken, with an average weight of $1.0 \mathrm{~kg}$. Chicken deaths were not due to disease but due to exhaustion during the journey from the farm to the slaughterhouse. The dead chickens were immediately taken to the Laboratory of the Jakarta Assessment Institute for Agricultural Technology (Jakarta AIAT) in South Jakarta, to be weighed and immediately chopped/milled using a chopper/grinder into a size of $2.5 \mathrm{~cm}$ or smaller.

Then the ground chickens were thoroughly mixed with additives and inoculums in accordance with the type of the treatment that has been designated. Furthermore, each $5 \mathrm{~kg}$ of the mixture was placed into a plastic box with a capacity of 5 liters, and then it was sealed using plaster/tape to ensure an anaerobic atmosphere. All plastic boxes were placed in a room temperature for a three weeks period of fermentation. After that, the fermented materials were then dried using an oven with a temperature of $60{ }^{\circ} \mathrm{C}$ until it reaches the water content of about $15 \%$. It was finally ground using a grinding machine with a 100 mesh sieve size (Despal et al., 2011; Utomo et al., 2013).

\section{Chemical and Data Analysis}

The parameters observed were: a) physical characteristics (aroma, color and texture), b) microbial content (TPC, Salmonella spp. and E. coli), and c) chemical analysis (protein, fat and energy). Microbial content analysis was conducted in the Microbiology Laboratory of Faculty of Veterinary Medicine, Bogor Agricultural University in Dramaga, Bogor, while the chemical analysis carried out in the Chemistry Laboratory of Livestock Research Institute in Ciawi, Bogor. The microbial analysis is conducted according to SNI No.: 2897-2008 (BSN, 2008), while the chemical analysis done according to AOAC (2000). The protein content was measured through destruction with sulfuric acid and the subsequent measurement of Kyeldahl Nitrogen using auto analyzer. Fat content was measured by extraction with petroleum spirit, whereas the gross energy content was measured using a Bomb Calorimeter.

Analysis of the data from all the measured parameters was done using analysis of variance (ANOVA), using the computer program of SPSS (Statistical Package for Social Sciences) version 21.0. If the results of statistical analysis showed significant differences among treatments, then the analysis was continued with Duncan's multiple 
range test (Mattjik and Sumertajaya, 2006).

\section{RESULTS AND DISCUSSION}

\section{Physical Characteristics}

The dry matter (DM) content of the minced chickens in this study was $47.4 \%$, which is much higher than the DM content of chicken or broiler meat which is only about 25.6\% (Dewi, 2013). The high DM content on the ground dead chickens was likely due to that it was not only consist of chicken meat alone but it was in the form of whole chickens which consisted of feathers, bones, offal and so forth.

As it is known that, to ensure the best fermentation process, the DM content in the fermented materials should be at least about $35 \%$ (Utomo et al., 2013). The DM content of the minced chicken used in this study was quite high (47.4\%), which is already eligible for the implementation of fermentation. However, the DM content decreased after being mixed with $20 \%$ molasses to $43.1 \%$, this is possibly due to the addition of the water content derived from the molasses. But on the contrary, the DM content increased to $52.4 \%$ after it was mixed with $20 \%$ molasses and $20 \%$ cornmeal, which might be due to the addition of the DM derived from the cornmeal.

The minced chicken had a fishy smell that is typical for the minced chicken meat (Table 1). The addition of molasses caused a slight change of the minced chicken aroma, which still smelled fishy, but there is an additional distinctive smell of the molasses. However, there was a slightly fishy odor reduction with the addition of molasses and cornmeal; nonetheless it was still smell a distinctive aroma of the molasses.

The minced chicken had a reddish color which is also typical color of the minced chicken meat, but those mixed with molasses the color was changed to dark red/black. When the minced chicken was mixed with molasses and cornmeal the color was changed to slightly lighter compare to if it was only mixed with molasses. There were no differences on the texture of the minced chicken at before and after mixed with molasses alone or with the addition of cornmeal. There were also no differences in the flavor, color and texture of the minced chicken at the time before and after mixed with all kinds of inoculums used in this study.

Based on the physical characteristics of the dead chickens after fermented, it seems that the fermentation process was successful resulting good quality silage. The silage resulted in this study had a fragrant aroma, dark in color, moist in texture, solid, did not clot and not slimy (Table 1). As it has been reported that a good silage has a) a fragrant aroma as it contains lactic acid, b) does

Table 1. Physical Characteristics of the Dead Chickens with Different Treatments at Before and After Fermentation for a 3 Weeks Period

\begin{tabular}{|c|c|c|c|c|c|c|}
\hline \multirow{2}{*}{$\begin{array}{c}\text { Treatments / } \\
\text { Fermentation Period }\end{array}$} & \multicolumn{3}{|c|}{ Molasses } & \multicolumn{3}{|c|}{ Molasses + Cornmeal } \\
\hline & Aroma & Color & Texture & Aroma & Color & Texture \\
\hline \multicolumn{7}{|l|}{ A. Before Fermentation } \\
\hline - Lactobacillus sp. & Fishy & $\begin{array}{l}\text { Reddish } \\
\text { Black }\end{array}$ & Soft & Slightly Fishy & $\begin{array}{l}\text { Light Reddish } \\
\text { Black }\end{array}$ & Soft \\
\hline - Streptomyces sp. & Fishy & $\begin{array}{l}\text { Reddish } \\
\text { Black }\end{array}$ & Soft & Slightly Fishy & $\begin{array}{l}\text { Light Reddish } \\
\text { Black }\end{array}$ & Soft \\
\hline $\begin{array}{l}\text { - Lactobacillus sp.+ } \\
\text { Streptomyces sp. }\end{array}$ & Fishy & $\begin{array}{l}\text { Reddish } \\
\text { Black }\end{array}$ & Soft & Slightly Fishy & $\begin{array}{l}\text { Light Reddish } \\
\text { Black }\end{array}$ & Soft \\
\hline \multicolumn{7}{|l|}{ B.After Fermentation } \\
\hline - Lactobacillus sp. & $\begin{array}{l}\text { Fresh \& } \\
\text { Sour }\end{array}$ & $\begin{array}{l}\text { Brown } \\
++\end{array}$ & $\begin{array}{c}\text { Watery } \\
++\end{array}$ & $\begin{array}{c}\text { Fresh \& Sour } \\
++\end{array}$ & Light Brown & Watery \\
\hline - Streptomyces sp. & $\begin{array}{l}\text { Fresh \& } \\
\text { Sour }\end{array}$ & $\begin{array}{c}\text { Brown } \\
+++\end{array}$ & $\begin{array}{l}\text { Watery } \\
\quad+\end{array}$ & $\begin{array}{c}\text { Fresh \& Sour } \\
++\end{array}$ & Light Brown & Watery \\
\hline $\begin{array}{l}\text { - Lactobacillus sp.+ } \\
\text { Streptomyces sp. }\end{array}$ & $\begin{array}{l}\text { Fresh \& } \\
\text { Sour }\end{array}$ & $\begin{array}{l}\text { Brown } \\
++\end{array}$ & $\begin{array}{c}\text { Watery } \\
++\end{array}$ & Fresh \& Sour & Light Brown & Watery \\
\hline
\end{tabular}


not have a pungent odor, c) has an intact texture, smooth, not slimy and not agglomerate (Saun and Heinrichs, 2008; Despal et al., 2011). Results of this study indicate that there was no significant effect on the physical characteristics of the fermented chicken given different types of treatments.

\section{Microbial Contents}

To ensure that the fermentation of dead chickens were safe to be used as a feed material, it is was necessary to measure the contaminated microbes. In fact, the chicken meat is perishable food which is very easily contaminated by microorganisms, as it is a very good medium for microbial growth. The types of pathogenic microbes often found in animal-based food ingredients are: Champhylobacter sp., Clostridium sp., Coliform, E. coli, Enterococci, Listeria sp., Salmonella sp., and Staphylococcus aureus. However, most types of microbes often contaminate the chicken meat and are often used as a reference for food safety are Salmonella sp. and E. coli (Gustiani, 2009).

In order to ensure food security, the maximum limit of the number of microbes or the total plate count (TPC) value allowed for carcass and meat of chickens are as much as $1 \times 10^{6} \mathrm{cfu} / \mathrm{g}$ or equivalent to $6 \log \mathrm{cfu} / \mathrm{g}(\mathrm{BSN}, 2009)$. The TPC value in all treatments used in this study at the time before and after fermentation is higher than that maximum limit. The TPC value at the time before fermentation ranged between 7.30 to $9.18 \log \mathrm{cfu} / \mathrm{g}$, while the value of the TPC after fermentation ranged from 7.00 to $8.49 \mathrm{log} \mathrm{cfu} / \mathrm{g}$ (Table 2). The lowest TPC value at before fermentation was the minced chickens mixed with molasses and Lactobacillus sp., while the highest TPC value when it was mixed with molasses, cornmeal, Lactobacillus sp. and Streptomyces $\underline{\mathrm{sp}}$. The high content of the TPC in the minced chickens was likely due to the addition of inoculums Lactobacillus sp. and Streptomyces sp. respectively amounted of $6 \log \mathrm{cfu} / \mathrm{g}$ of fermented material. Another possibility was due to that the chickens had died about 2-3 hours before they were ground, so there had been some contaminations from the environment and microbial growth both on the outside and inside of the chicken body.

It seemed that the high number of the TPC on a fermented minced chicken mixture was not directly related to the insecurity of the material to be used as a food ingredient. This product was not to be intended for direct human consumption, but it will be used as a source of protein in the manufacture of feed for animal or catfish. As it had been noted earlier that the high content of the TPC on the fermented materials is was due to the addition of $10^{6} \mathrm{cfu} / \mathrm{g}$ each of inoculums in the form of Lactobacillus sp. and Streptomyces sp. Both types of inoculums were a test material to determine its effectiveness in helping the fermentation process.

Therefore, the maximum limit set by BSN (2009) for the TPC value which is $6 \mathrm{log} \mathrm{cfu} / \mathrm{g}$ is only for the chicken meat or carcass that will be consumed directly by humans. It appears that the value of TPC on all materials fermented in this study tended to have a lower value at the time after fermentation compared to before fermentation (Table 2). The use of Inoculum-2 tended to increase the content of TPC at the time before fermentation, especially if it was used in conjunction with the Inoculum-1. However, the numbers of TPC at the time after fermentation were not significantly differences $(\mathrm{P}>0.05)$ among all treatments. This suggests that the microbe could not be evolved or died during the fermentation process.

It was shown that there was a positive interaction on the content of the TPC at the time before fermentation between the uses Accelerator1 with the type of Inoculum used. The use of Inoculum- 2 caused a higher content of TPC $(8.38$ $\mathrm{cfu} / \mathrm{g})$ compared to the Inoculum-1 (7.30 cfu/g). The content of TPC was also likely to be increased $(8.88 \mathrm{cfu} / \mathrm{g})$, if the Inoculum-3 was used. However, after the fermentation period, a significant interaction occurred only between the use of Accelerator- 2 with the type of inoculum used. It was shown that the use of Inoculum-1 simultaneously with the Accelerator- 2 produced the lowest content of TPC, amounting $7.30 \mathrm{cfu} / \mathrm{g}$.

Although the content of the TPC on the materials tested in this study exceeded the maximum limit specified, but in fact the material is safe from the danger of the pathogenic bacteria. The Salmonella sp. content in the material before and after fermentation was negative per 25 gram (Table 2). This is in accordance with the recommended limit of Salmonella sp. contamination in chicken meat by BSN (2009). In addition, the $E$. coli content in all of the material was also very low, which only amounted $<3 \mathrm{cfu} / \mathrm{g}$, a figure much lower than the maximum allowed limit, which is $10 \mathrm{cfu} / \mathrm{g}$. Therefore, materials used in this study are very safe to be used as an 
Table 2. Microbial Contents of the Dead Chickens with Different Treatments at Before and After Fermentation for a 3 Weeks Period

\begin{tabular}{|c|c|c|c|c|c|c|c|}
\hline \multirow[b]{2}{*}{ Accelerator } & \multirow[b]{2}{*}{ Inoculum } & \multicolumn{3}{|c|}{ Before Fermentation } & \multicolumn{3}{|c|}{ After 3 Weeks Fermentation } \\
\hline & & $\begin{array}{c}\text { TPC } \\
\text { (Log cfu/g) }\end{array}$ & $\begin{array}{l}\text { Salmonella } \\
\text { (per } 25 \mathrm{~g} \text { ) }\end{array}$ & $\begin{array}{c}\text { E. coli } \\
\text { (MPN/g) }\end{array}$ & $\begin{array}{c}\text { TPC } \\
\text { (Log cfu/g) }\end{array}$ & $\begin{array}{c}\text { Salmonella } \\
\text { (per } 25 \mathrm{~g} \text { ) }\end{array}$ & $\begin{array}{c}\text { E. coli } \\
\text { (MPN/g) }\end{array}$ \\
\hline Acc-1 & & 8.19 & Negative & $<3$ & 7.63 & Negative & $<3$ \\
\hline Acc-2 & & 8.72 & Negative & $<3$ & 8.14 & Negative & $<3$ \\
\hline \multicolumn{2}{|c|}{ Mean } & 8.46 & Negative & $<3$ & 7.89 & Negative & $<3$ \\
\hline & Ino-1 & $7.86^{\mathrm{a}}$ & Negative & $<3$ & 7.15 & Negative & $<3$ \\
\hline & Ino-2 & $8.48^{\mathrm{ab}}$ & Negative & $<3$ & 8.45 & Negative & $<3$ \\
\hline & Ino-3 & $9.02^{b}$ & Negative & $<3$ & 8.04 & Negative & $<3$ \\
\hline \multicolumn{2}{|c|}{ Mean } & 8.45 & Negative & $<3$ & 7.88 & Negative & $<3$ \\
\hline \multirow[t]{3}{*}{ Acc-1 } & Ino-1 & $7.30^{\mathrm{a}}$ & Negative & $<3$ & 7.00 & Negative & $<3$ \\
\hline & Ino-2 & $8.38^{\mathrm{b}}$ & Negative & $<3$ & 8.28 & Negative & $<3$ \\
\hline & Ino-3 & $8.88^{\mathrm{b}}$ & Negative & $<3$ & 7.60 & Negative & $<3$ \\
\hline \multicolumn{2}{|c|}{ Mean } & 8.19 & Negative & $<3$ & 7.63 & Negative & $<3$ \\
\hline \multirow[t]{3}{*}{ Acc-2 } & Ino-1 & 8.42 & Negative & $<3$ & $7.30^{\mathrm{a}}$ & Negative & $<3$ \\
\hline & Ino-2 & 8.59 & Negative & $<3$ & $8.62^{\mathrm{ab}}$ & Negative & $<3$ \\
\hline & Ino-3 & 9.18 & Negative & $<3$ & $8.49^{\mathrm{b}}$ & Negative & $<3$ \\
\hline \multicolumn{2}{|c|}{ Mean } & 8.73 & Negative & $<3$ & 8.14 & Negative & $<3$ \\
\hline \multicolumn{8}{|l|}{ Main Effect : } \\
\hline \multicolumn{2}{|l|}{ Accelerator } & NS & NS & NS & NS & NS & NS \\
\hline \multicolumn{2}{|l|}{ Inoculum } & $<0.01$ & NS & NS & NS & NS & NS \\
\hline \multicolumn{2}{|c|}{ Accelerator x Inoculum } & $<0.01$ & NS & NS & $<0.01$ & NS & NS \\
\hline
\end{tabular}

a-b Means within a row with no common superscript differ significantly $(\mathrm{P}<0.05)$. Acc-1 = Accelerator -1 : Molasses; Acc-2 = Accelerator - 2: Molasses + Cornmeal; Ino-1 = Inoculum - 1: Lactobacillus sp.; Ino-2 = Inoculum - 2: Streptomyces sp.; Ino-3 = Inoculum -3: Lactobacillus sp. + Streptomyces sp.

ingredient for the formulation of feed for animal or catfish.

The low content of Salmonella sp. and E. coli bacteria in the tested material showed that the processing and handling of materials in this study were quite hygienic with a fairly good level of sanitation. Contamination by the Salmonella sp. can only occur if there is contamination from fecal of infected chickens during processing or handling. Contamination is also easily occurring if the process of cutting and handling of chickens conducted at the same site or adjacent to the raising of the contaminated chicken. The Salmonella sp. will also breed well if the environment is hot and humid (Utari et al., 2016). The E. coli is a normal micro flora present in the digestive tract and is often found in water contaminated by animal or human feces. The existence of the $E$. coli bacteria is often used as an indicator to show that the level of poor sanitation and non hygienic handling process (Kornacki and Johnson, 2001).

In this research, the process for handling chicken was not similar to the commonly carried out for broiler chicken, such as slaughtering, plucking, offal cleaning, cutting, packaging etc., so it was less likely to be contaminated by microbes. The chances of contamination by 
microbes was also minimum as the chicken used was the freshly dead chickens and their death was not due to diseases or illness but because of fatigue caused by transportation from farm to the market/collecting points or slaughterhouse. The chicken was also never washed with water, but immediately milled and blended with accelerators and inoculums for fermentation. So it is unlikely to be contaminated by microbes contained in the water, but instead the possibility of microbes will be dead or stunted due to the present of the materials used as the fermentation accelerators and inoculums.

\section{Nutritional Contents}

As it was shown in Table 3 that the protein content of the fermented chicken was significantly higher $(\mathrm{P}<0.05)$ when using the Accelerator-1 (18.7\%) compared to the Accelerator-2 (16.5\%). Additionally, the use of Inoculum-1 tended to produce a higher protein content (19.5\%) compared to the Inoculum-2 (17.8\%) or Inoculum-3 (16.1\%).

There was a positive interaction on the protein content of the fermented chicken between the types of Accelerator with the type of Inoculum used. The use of Accelerator-1 with Inoculum-1 or Inoculum-2 produced a higher $(\mathrm{P}<0.05)$ protein content (mean of 19.5\%) than the use of Inoculum-3 (17.3\%). When using the Accelerator2 , the protein was better produced if the Inoculum-1 was used $(18.7 \%)$. However, when using the Inoculum-2 (16.0\%) and Inoculum-3 $(14.8 \%)$ resulted in a lower protein content.

There were no significant differences $(\mathrm{P}>0.05)$ in the fat content of the chicken after fermentation period when using different types of Inoculum (Table 3). But there was a positive interaction in fat content between the use of Accelerator-2 and the type of inoculum used. The use of Accelerator-2 with Inoculum-1 or Inoculum-2 produced a fat content which was not significantly different $(\mathrm{P}>0.05)$ with a value of $3.31 \%$. However, with the use of Inoculum-3 resulted in a fairly high fat content $(36.2 \%)$.

There was no difference in the gross energy contents in chickens which were fermented using various types of Accelerator and Inoculum. There was also no interaction of the value of gross energy content between all types of Accelerator and Inoculum used. The average gross energy content of the chicken after fermented was 2308 $\mathrm{kcal} / \mathrm{kg}$ (Table 3 ).

The protein content of the chicken meat generally ranges between $16-23 \%$ and the fat content of between 1.5 to $13.0 \%$ (Aberle et al., 2001; Rosyidi et al., 2009). The protein content of the fermented dead chickens in this study was between 14.8 to $19.6 \%$, which is almost equal to the protein content of the chicken meat; however, it has a very high fat content of between 31.8 to $43.5 \%$. It is seen that the whole chickens which were fermented with molasses and cornmeal together was not cause any significant effect on the protein content, but the fat content increased almost two-fold.

Based on the data of the protein content obtained from this study, the dead chickens was best fermented using molasses as the accelerator and Lactobacillus sp. or Streptomyces sp. as the inoculums. The use of Lactobacillus sp. may also be combined with molasses and cornmeal as the accelerator because it produces a protein that is was not significantly different (19.3\% vs. 18.7\%). But the use of Streptomyces sp. as inoculum along with molasses and cornmeal should not be done because it would lead to a decrease in protein content (19.6\% to $16.0 \%)$. However, based on the fat content, the fermentation of the dead chickens could be done using molasses and cornmeal as the accelerator and the Lactobacillus sp. or Streptomyces sp. as the inoculum, because the fat contents of the fermented product were relatively similar (mean of $37.8 \%$ ). Therefore, in order to obtain a best fermentation product in terms of protein and fat content, the dead chicken should be fermented using molasses and cornmeal as the accelerator and Lactobacillus sp. as the inoculum. The poultry by product meal which is usually used as the catfish feed in the United States contains approximately $58-65 \%$ protein and 10 $14 \%$ crude fat, and it consists of only heads, feet, underdeveloped eggs and visceral organs, but it does not contain feather ( $\mathrm{Li}$ and Robinson, 2013). This means that the protein content of the fermented dead chicken in this study (mean of $19.0 \%$ ) was far too low, and the fat (mean of $37.8 \%$ ) was far too high compared to the poultry by product meal used as catfish feed. The protein content of the dead chickens fermentation obtained in this study was also still very low compared to the protein content of the materials commonly used as ingredients in the manufacture of animal feed or catfish, such as fish meal, blood meal, mustard oil cake and soybean meal which usually contain protein between 41.9 to $90.0 \%$. However, the fat content is too high compared to those materials which contain fat between 1.40- 
Table 3. Nutrient Contents of the Dead Chickens with Different Treatments After Fermentation for a 3 Weeks Period

\begin{tabular}{ccccc}
\hline Accelerator & Inoculum & Protein $(\%)$ & Fat $(\%)$ & Gross Energy $(\mathrm{kcal} / \mathrm{kg})$ \\
\hline Acc-1 & & $18.7^{\mathrm{a}}$ & $42.3^{\mathrm{a}}$ & 2258 \\
Acc-2 & & $16.5^{\mathrm{b}}$ & $34.1^{\mathrm{b}}$ & 2357 \\
& Ino-1 & $19.5^{\mathrm{a}}$ & 38.0 & 2263 \\
& Ino-2 & $17.8^{\mathrm{ab}}$ & 37.7 & 2335 \\
& Ino-3 & $16.1^{\mathrm{b}}$ & 39.0 & 2325 \\
\multicolumn{1}{c}{ Acc-1 } & Ino-1 & $19.3^{\mathrm{a}}$ & 41.6 & 2210 \\
& Ino-2 & $19.6^{\mathrm{ab}}$ & 43.5 & 2290 \\
\multicolumn{1}{c}{ Acc-2 } & Ino-3 & $17.3^{\mathrm{b}}$ & 41.7 & 2275 \\
& Ino-1 & $18.7^{\mathrm{a}}$ & $34.4^{\mathrm{ab}}$ & 2315 \\
& Ino-2 & $16.0^{\mathrm{b}}$ & $31.8^{\mathrm{a}}$ & 2380 \\
Main Effect : & Ino-3 & $14.8^{\mathrm{b}}$ & $36.2^{\mathrm{b}}$ & 2375 \\
Accelerator & & $<0.01$ & & \\
Inoculum & & $<0.01$ & $<0.01$ & NS \\
Accelerator x Inoculum & & $<0.001$ & NS & NS \\
\hline
\end{tabular}

${ }^{\mathrm{a}-\mathrm{b}}$ Means within a row with no common superscript differ significantly $(\mathrm{P}<0.05)$. Acc- $1=$ Accelerator -1 : Molasses; Acc-2 = Accelerator - 2: Molasses + Cornmeal; Ino-1 = Inoculum - 1: Lactobacillus sp.; Ino-2 = Inoculum - 2: Streptomyces sp.; Ino-3 = Inoculum -3: Lactobacillus sp. + Streptomyces sp.

\section{$21.0 \%$ (Nahar et al., 2000).}

Due to its high fat content, the fermented dead chicken will be difficult to pellet if it is to be used as an ingredient in the manufacture of animal or catfish feed. The fat content in the different types of pellet for catfish feed on the market generally only have a fat content of about $2-10 \%$ (Robinson et al., 2006). Therefore, before it can be used as feed material in the manufacture of pellets for animal or catfish feed, the fermented dead chicken should be first mixed with other materials that can reduce its fat content, such as cassava pomace flour or calcium carbonate.

\section{CONCLUSION}

The fermentation process in this study was successful as it produced a good quality silage which had a fragrant aroma, dark in color, moist in texture, solid, did not clot and not slimy. The dead chicken and its mixture used for the fermentation had a slightly high in the TPC content but it was safe from the danger of the pathogenic bacteria. In order to obtain a best fermented product in terms of the protein and fat content, the dead chicken should be fermented using molasses and cornmeal as the accelerator and Lactobacillus sp. as the inoculum.

\section{REFERENCES}

Aberle, E.D., C.J. Forest., H.B. Hedrick., M.D. Judge and R.A. Merkel. 2001. The Principle of Meat Science. W.H. Freeman and Co, San Fransisco.

AOAC. 2000. Official Methods of Analyses. 17 ${ }^{\text {th }}$ Ed. Association of Official Analytical Chemist, Washington DC, USA.

BSN. 2008. Metode pengujian cemaran mikroba dalam daging, telur dan susu, serta hasil olahannya. SNI No.: 2897-2008. Badan Standardisasi Nasional. Jakarta.

BSN. 2009. Mutu karkas dan daging ayam. SNI No.: 3924-2009. Badan Standardisasi 
Nasional. Jakarta.

Bujalance, C., M. Jiminez-Velera, E. Moreno and A. Ruiz-Bravo. 2006. A selective differential medium for Lactobacillus plantarum. J. Microbiol. Methods. 66:572-575.

Chauvin, C., S. Hillion, L. Balaine, V. Michel, J. Peraste, I. Petetin, C. Lupo and S. Le Bouquin. 2011. Factors associated with mortality of broilers during transport to slaughterhouse. Anim. 5(2):287-293.

Core, J. 2005. Poultry Pathogen Models for Predictive Microbiology. Agric. Res. 53(6): 18-19.

Despal, I.G., Permana, S.N. Safarina dan A.J. Tatra. 2011. Penggunaan berbagai sumber karbohidrat terlarut air untuk meningkatkan kualitas silase daun Rami. Media Peternakan. 43:69-76.

Dewi, S.H.C. 2013. Kualitas kimia daging ayam kampung dengan ransum berbasis konsentrat broiler. Jurnal Agri Sains. 4(6): 42-49.

Ditjen PKH. 2015. Statistik Peternakan dan Kesehatan Hewan. Direktorat Jenderal Peternakan dan Kesehatan Hewan. Kementerian Pertanian. Jakarta.

Gustiani, E. 2009. Pengendalian Cemaran Mikroba pada Bahan Pangan Asal Ternak (Daging dan Susu) Mulai dari Peternakan Sampai Dihidangkan. Jurnal Litbang Pertanian. 28(3): 96-100.

Haslam, S.M., T.G. Knowles, S.N. Brown, L.J. Wilkins, S.C. Kestin, P.D. Warriss and C.J. Nicol. 2008. Prevalence and factors associated with it, of birds dead on arrival at the slaughterhouse and other rejection conditions in broiler chickens. British Poult. Sci. 49(6): 685-696.

Heinritz, S. 2011. Ensiling Suitability of High Protein Tropical Forages and their Nutritional Value for Feeding Pigs. Diploma Thesis. University of Hohenheim. Stutgart.

Jamarun, N., I. Ryanto dan L. Sanda. 2014. Pengaruh Penggunaan Berbagai Bahan Sumber Karbohidrat terhadap Kualitas Silase Pucuk Tebu. J. Peternakan Indonesia. 16(2):114-118.

Jani, S.A., R. Soni, H. Patel, B. Prajapati dan G. Patel. 2014. Screening, isolation and characterization of keratin degrading actinomycetes: Streptomyces sp. and Saccharothrix xinjiangensi and analyzing their significance for production of keratinolytic protease and feed grade aminoacids. Int. J. Curr. Microbiol. App. Sci. 3(9):940-955.

Kinley, B., J. Rieck, P. Dawson, and X. Jiang. 2010. Analysis of Salmonella and Enterococci isolated from rendered animal product (Clinical report). Can. J. Microbiol. 56(1):65-73.

Kornacki, J.L. and J.L. Johnson. 2001. Enterobacteriaceae, Coliforms and Escherichia coli as Quality and Safety Indicators. In: F.P. Downes and K. Ito (Editors). Compendium of Methods for the Microbiological Examination of Foods. $4^{\text {th }}$ Edition. American Public Health Association. Washington DC. USA. Pp. 6982.

Li, M.H. and E.H. Robinson. 2013. Feed Ingredients and Feeds for Channel Catfish. Southern Regional Aquaculture Center. Publication No. 1806. February 2013. National Institute of Food and Agriculture. United States Department of Agriculture. Washington DC. USA.

Manivasagan, P., J. Venkatesan, K. Sivakumar and S. Kim. 2013. Production, characterization and antioxidant potential of protease from Streptomyces sp. MAB18 using poultry wastes. BioMed Research International. Vol. 2013, Article ID 496586, 12 pages.

Mattjik, A.A., Sumertajaya, I.M. 2006. Perancangan Percobaan. Institut Pertanian Bogor Press. Bogor.

Nahar, Z., A.K.M. A. Shah, R.K. Bhandari, M.H. Ali and S. Dewan. 2000. Effect of different feeds on growth, survival and production of African catfish (Clarias gariepinus Burchell). Bangladesh J. Fish. Res. 4 (2): 121-126.

Nijdam, E., A. R. M. Zailan, J. H. H. Van Eck, E. Decuypere and J. A. Stegeman. 2006. Processing, products and food safety: Pathological features in dead on arrival broilers with special reference to heart disorders. Poult. Sci. 85: 1303-1308.

Petracci, M., M. Bianchi and C. Caviani. 2005. Preslaughter factors affecting mortality, liveweight loss and carcass quality in broiler chickens. Proc. XVII Eur. Symp. Qual. Poul. Meat. Doorwerth, The Nederlands. Pp. 104107.

Robinson, E.H., M.H. Li, D.F. Oberle, and B.G. Bosworth. 2006. Efficacy of High-Protein "Finishing" Diets on Growth, Fattiness, and Processing Yield of Channel Catfish, 
Ictalurus punctatus. J. Appl. Aquacult. 18 (3): $37-52$.

Rosyidi, D., A. Susilo dan R. Muhbianto. 2009. Pengaruh Penambahan Limbah Udang Terfermentasi Aspergillus Niger pada Pakan terhadap Kualitas Fisik Daging Ayam Broiler. Jurnal Ilmu dan Teknologi Hasil Ternak. 4(1):1-10.

Saun, R.J.V. and A.J. Heinrichs. 2008. Troubleshooting silage problems: How to identify potential problem. Proceddings of the Mid-Atlantic Conference; Pennsylvania, 26-26 May 2008. Penn State's Collage. Pp. 2-10.

Shata, H.M.A.H. and M.A.F. Farid. 2013. Medium optimization for keratinase production by a local Streptomyces sp. NRC 13S under solid state fermentation. J. Appl Biol. Chem. 56(2):119-129.

Steubing, P.M. 1993. Isolation of an unknown bacterium from soil in: Tested Studies for
Laboratory Teaching Volume 14. (C.A. Goldman, editor). Proceedings of the $14^{\text {th }}$ Workshop/Conference of The Association for Biology Laboratory Education (ABLE).

Utari, L.K., Rr. Riyanti dan P.E. Santosa. 2016. Status Mikrobiologis Daging Broiler Di Pasar Tradisional Kabupaten Pringsewu. Jurnal Ilmiah Peternakan Terpadu. 4(1):5962.

Utomo, R.S., P.S. Budhi, dan I.F. Astuti. 2013. Pengaruh level Onggok sebagai aditif terhadap kualitas silase isi rumen sapi. Buletin Peternakan 37(3):173-180.

Voslarova, E., B. Janackova, F. Vitula, A. Kozak and V. Vecerek. 2007. Effects of transport distance and the season of the year on death rates among hens and roosters in transport to poultry processing plants in the Czech Republic in the period from 1997-2004. Vet. Med. 52: 262-266. 